\title{
THE SOCIAL DEMOCRATIC PARTY (PSD) IN ROMANIA WITHIN THE FRAMEWORK OF THE ROMANIAN AND EUROPEAN LEFT. THE PSD MANIFESTO FOR THE 2016 PARLIAMENTARIAN ELECTIONS
}

\author{
Horia-Alin LUPU \\ $\mathrm{PhD}$ candidate, \\ College of Political, Administrative and Communication Sciences (FSPAC), \\ Babes-Bolyai University Cluj-Napoca \\ lupu@fspac.ro, horialupu@yahoo.com
}

DOI:10.24193/OJMNE.2017.23.04

\begin{abstract}
The following contribution aims to shed light upon some facts that can be relevant to the academic field as well as to the practical social/political life, facts related to whether the Romanian Social Democratic Party (Partidul Social Democrat, PSD) properly belongs to the left wing political spectrum in Europe (more precisely to the ideological family of socialists and social-democrats) and also regarding its continuity with the traditional Romanian (interwar period and pre-1918) left. I will review the main theoretical approaches concerning the role and the functions of ideology for political parties and, as a case study, I will analyze the party's political programs and electoral manifestos for the 2016 legislative elections.
\end{abstract}

Keywords: ideology, social-democracy, political party, political program, electoral manifesto.

\section{Introduction}

This article aims to realize a research whose main object is the Social Democratic Party in Romania (PSD), currently the main parliamentary and governing party ${ }^{12}$ (since December 2016 - January 2017), as well as the main national political actor, also taking into account the votes and mandates obtained at the local elections in June, 2016. The main aspects which will be analyzed will be the party ideology, starting with the official documents of the party (political programs and electoral materials/manifestos) used in the electoral campaign of November-December 2016, whose validity was repeatedly reasserted by PSD and its leading staff up to the present. These will be compared mainly with the

\footnotetext{
${ }^{12}$ Forming the coalition cabinet, as major partner, together with the Alliance of Liberals and Democrats Party (ALDE).
} 
Issue no. $23 / 2017$

typical positioning on similar themes of European parties with the same ideological orientation, and colleagues of the PSD in transnational party organizations. Also, in order to properly define de context, I will present aspects linked to the historical evolution of socialism and social-democracy, I will try to synthesize the historical context of the main values and ideological benchmarks of the evolution of the socialist and social-democratic left at an international and European level, including also the main theoretical and methodological approaches regarding the research and measurement of the ideological position of political parties.

After Romania's accession to the European Council (1993) and especially to the European Union (2007), but mainly after PSD's admission to the Socialist International (2003) and later to the Party of European Socialists (2005), the affiliation movement following a similar trend with the majority of "classical" left parties in Central and Eastern Europe, the problem of certain structural, systematical or significant differences between political parties in Western Europe and their equivalents as ideological framing to the East lost most of its significance.

Thus, the series of articles and, later, books, which have Herbert Kitschelt as author/co-author (Kitschelt, 1992; 1995; Kitschelt, Mansfeldova, Markowski, Toka, 1999) suggest the existence of a different ideological placement, perhaps even a radically distinct one, of left and right parties from the countries of the former socialist and soviet bloc compared with their equivalents from the West, depending on the existing types of cleavages in post-communist countries and on the way in which these combine with each other under the pressure from parties and political leaders to mobilize/activate them. The aforementioned events, and especially the affiliation of the majority of East-European parties to international party organization, resulted in a growing pressure toward convergence, at least at the level of doctrines and official political documents.

\section{Terminological specifications}

At the conceptual/terminological level, we can say that nowadays the terms socialism and social-democracy are synonyms (with a touch of complementarity) or functional equivalents. According to various authors, there are several explanations regarding their distinct meanings from the past. Ware (1996, pp. 33-35) mentions two of these. According to the first, we can discuss about social-democracy especially after the left-wing (socialists) parties were contaminated with the economic ideas of John Maynard Keynes around the 
Issue no. 23/2017

Second World War (as an essential turning spot being the Congress of the German Social Democratic Party, SPD from Bad-Godesberg, in 1959), concerning the emphasis upon mixed (market) economy, unlike the previous vision which insisted on socializing/nationalizing the economy and the means of production.

A second distinction mentioned by Ware would be the one of connection (existent or not) between parties and trade unions. Thus, parties which maintained close connections with these (regardless of whether they were actually created by the trade unions or not) would represent the social-democratic type (the classic example of a left-wing political party created by trade unions - British Labor Party - appeared as a result of a motion voted in the year 1900 by the British Trade Union Congress) and those with weak connections with trade unions would represent the socialist type (the case of the French Socialist Party, created in the last quarter of the $19^{\text {th }}$ century by a group of intellectuals and revolutionaries).

In his study (1998, p. 185), A. Carpinschi equates social democracy with "parliamentary socialism" as he suggests that there is a certain closeness to the "revisionism" of the late XIX century (for further details see below) and emphasizing, unlike Ware in the first distinction, two characteristics: the reconciliation of socialism with the liberaldemocratic system and with the capitalist society.

\section{Socialism and social-democracy - elements of history of thinking}

Depending on the authors, one can find the roots of a proto-socialist type of thinking with the classical Greek or late-medieval political thinking, the names that are cited the most being Plato (The Republic) and Thomas Morus (Utopia), according to Ball and Dagger (2000, p. 128). References can also be made to fragments from The New Testament or to the practices of the early Christians from the first centuries A. D., up until the adoption of Christianism as the official religion in the Roman Empire.

However, the true precursors would be those known as the "utopian socialists", category which includes names such as Claude-Henry de Saint-Simon, Auguste Compte (founder and supporter of positivism or "social physics", as he intended to call what we label nowadays "social science"), Charles Fourrier and Robert Owen (Ball, Dagger, 2000, pp. 130132). Despite the differences among them, these socialists were the exponents of a certain Enlightenment-type, planning oriented maximalism, critics of capitalism as a generator of excessive selfishness and waste, unscientific and encouraging immoral educational models. The suggested solutions, be it at a macro-theoretical level or at micro-applicative one 
Issue no. $23 / 2017$

emphasized the communitarian side of human nature and the importance of the interaction between individuals, the use of scientific knowledge and expertise, the power of motivation and the role of education in the success and development of communities and society.

The socialist thinking that we know today was to be truly structured in the post-Hegel period, its ideas being laid down by Karl Marx and Friederich Engels. The process that Marx started and which he continued together with his co-author, Engels, was extensive, systematic and claimed a scientific nature for itself (a claim underscored after Marx death).

One of the defining elements of Marxism would be the takeover and development of the G. W. F. Hegel dialectic vision of history, in which the relevant advancement is preceded by the ruptures/alienations, expressed through the thesis/antithesis conflict and the advent of progress through synthesis (Hegel, 2000/1807). Another would be the collective and communitarian perspective over society and individuals, the social class and membership to it having a decisive relevance for one's identity. The "engine" of history for Marx and Engels is represented by the fight for survival and for progress of the individuals/communities, through a combination of evolution and conflicts in which the class struggle (and the exploitation that comes with it, generated by the type of relation with the means of production) is essential. Those who possess, master and control the means of production are the ones who will control the power in society (political power included, political institutions being subordinated and functionally dependent on the economy; the same thing with the ideology - the prevalent pattern of thought from/about society, which generates a "false consciousness" of those who are exploited). Those who are reduced by the need of survival/economic gain to the state of being associated with them (slaves, peasants, proletarians/workers) are subjected to exploitation (Ball, Dagger, 2000, pp. 132-147).

Unlike utopian socialists, for Marx and Engels exploitation has a systematic character rather than a moral one. In capitalism, the only freedom that exist belongs to the capital (and not to the entrepreneur), this reality is what generates alienation; the capitalist himself is forced to obey to the logic of its functionality (Marx, Engels, 1962/1848). At the foundation of exploitation and the class struggled lies the private propriety and its emergence (Marx, Engels, 1956/1845).

At the core of the class struggle is the struggle of the other social classes to take the place of the exploiting class, and this mechanism seems to be unstoppable. The takeover of power by the working class should end this race and the internal contradictions accumulated by capitalism. This working class, which is a "the universal class" has as a purpose its own 
Issue no. $23 / 2017$

abolition and the end of exploitation. This would lead (with an intermezzo of "the dictatorship of the proletarians", destined to consolidate the temporary control of the working class over the state and society) to the dissolution, in an undefined interval, of the private propriety, of the state, even of the process of labor as known by us, and to a society that was forecasted as open/democratic (Ball, Dagger, 2000, pp. 132-147).

Another important trend in the structuring and evolution of socialist thought and doctrine was the revisionism, which emerged mostly after the death of Marx (1883) and Engels (1895). Its main exponent, Eduard Bernstein, in his work Evolutionary Socialism stresses the progresses achieved in a rather short period of time, by the socialist and tradeunion movement from Germany thus invalidating Marx's predictions that "the rich are going to be richer, and the poor will became poorer". He opposes, due to moral reasons (invoking Kant) a bloody revolution and the dictatorship of the proletariat, supporting the immediate interests of the working class and advocates for the constant and gradual improvement of these through political and social actions in a democratic environment (Berstein, 1907/1899; Ball, Dagger, 2000, pp. 154-155).

The last author I will mention, Vladimir Ilich Ulyanov (Lenin), is a critic of revisionism (considering it as collaborating with the bourgeoisie) and is the one who moves on from the socialist/social democratic way of thinking to communism. Alongside radicalization of ideas - the critique brought to "parliamentary-socialism", trade unions and Western working class for the false consciousness induced by the capitalists and the apologetic stance towards the revolutionary avantgarde/avantgarde party and of the democratic centralism (Ball, Dagger, 2000, pp. 156-159) - the latter making possible for the authoritarian/totalitarian party and rule to emerge, Lenin contributes to the development of leftist ideas by introducing and defining the concept of imperialism (Lenin, Imperialism, the most advanced stage of capitalism, 1916). In this work, who's topics are still being reused in different political and ideological contexts even to this day, Lenin upholds that the progress of developed societies (which already are in the imperialist stage) is based on the exploitation of underdeveloped nations and by doing so, the members of the advanced nations benefit from that in integrality (even if in different degrees, taking into account their social class). Therefore, the emergence of the socialist revolutions in the exploited societies is justified. 
Issue no. $23 / 2017$

\section{The institutional history of socialism and social democracy in Europe}

Since their birth, in the second half of the XIX ${ }^{\text {th }}$ century, the socialist and socialdemocratic parties had two main objectives: to obtain political rights for the working class (the - at least male - universal suffrage) and, together with the trade unions, to provision social and economic rights (labor related) for them (Gallager, Laver, Mair, 2002, p. 204). Evolving together reunited in the Second Socialist International (1889-1914), which has served them as a debate forum among Marxists and revisionists (later, after 1905, the Bolsheviks enter the scene too) as well as an umbrella for different existing currents orthodox revolutionary Marxism, anarchism, revisionism, social evolutive fabianism and Leninism (Carpinschi, 1998, p. 176). A common and constant trait of this period is how important the shared perception over the importance of internationalism, which supports the transnational interests of the workers (the exploited class) in their fight against the exploitation represented by the global capitalism.

An example of success for this period, in spite of an official interdiction between 1878 and 1890, was the German Social-Democratic Party (SPD). During the first decades of the $\mathrm{XX}^{\text {th }}$ century, this party, which was organized as a mass party, had more than 1 million members, a budget of 5 million Reichmarks, its own media, a central school in Berlin for the education of the workers elite and an umbrella of associations (of judicial/legal assistance, educational, cultural, sportive and recreational) developed around the party and the trade unions. In 1912, as number MPs, SPD became the most important party in the Reichstag.

Therefore, at the organizational level, we have what Maurice Duverger calls a typical mass party, with ramification over the territory, with constant activities at the subsidiaries level (the branches of the party), ideologically structured and democratically financed, in which the power is held by the formally (and, at least theoretically speaking, democratically) chosen leadership of the party and not by an informal elite represented by MPs (Carpinschi, 1998, p. 176). The efficiency of the SPD is proven by the improvement of the situation of the socio-political rights as well as the economic conditions of the German working class until the start of the First World War, although the party remains what Sigismund Neumann calls "the party of social integration", making it easier way for the integration of the working class in a social and cultural web which engulfs them, as the author says, "from the cradle to the grave" (Neumann, 1956, p. 47). But the political integration, in spite of the progresses made, was not possible. The other parties and political forces united against the socialists/socialdemocrats due to the perception of a threat which the socialists could pose to the system 
Issue no. 23/2017

itself. This reality is more or less characteristic for all the European states where such movements existed.

The following event in the evolution of socialist and social-democratic parties is the First World War, with the blow given by it to internationalism (most of the socialist representatives in the European legislatives voted in favor of military expenditures of their nations, involved in a "capitalist war") and connected with it but far more important, the Russian October Revolution of 1917 (Ware, 1996, p. 34). Following this stage, most of the radical leftists of the socialist parties and social democratic movements break up with them, creating communist parties; The Third (Communist) International is founded in 1919.

During the interwar period, in spite of the fact that the (male) universal suffrage already existed in Europe (partly due to their pressure), the socialist parties are marginal as a political influence ("victims of their own success" in mobilizing the working class electorate, as mentioned above and underlined by Kirchheimer, 1966). Their access to government is limited (Sweden being an exception), as well as the capacity to influence the society through public politics.

The real opening into activity of these parties appears only after the Second World War. From the end of the 1940's and all the way to today, with certain fluctuations in time and differences from nation to nation, socialists and social-democrats become, on the electoral results level, one of the two main political families in Europe (Gallagher, Laver, Mair, 2002, p. 206) alongside and in competition also with the popular parties (conservatives and Christian-democrats). Creators and supporters of the welfare state, moderate and constant promoters of European integration (in ECCS, EEC, EC and EU), the representatives of this ideological line of thought gave up their Marxist inheritance. Two main events mark these process: The First Congress of the Socialist International in Frankfurt am Main (1951) and, most important, the Congress of the German Social-Democratic Party in Bad-Godesberg (1959). Within these events the support for democratic organization of the society and the option for a mixed economy is asserted (Carpinschi, 1998, pp. 187, 190).

From an organisational point of view, the transition from a mass party to a catch-all party is made. Its five characteristics (stated by Otto Kirchheimer) are the following: 1) drastic reduction of the party's ideological baggage; 2) the growing in importance of leaders; 3) the loss of the importance of the individual members; 4) and of what the author calls "classe-gardée" (a social class towards which the political message is specifically directed); 
5) securing access to a variety of interest groups for financial and electoral reasons (Kirchheimer, 1966, p. 190).

The '60s bring the appearance of the New Left (feminist, antiwar) and a new type of competition to the left of social-democracy, amplified in the 1980-1990 by the emergence of the Green parties (Gallagher, Laver, Mair, 2002, pp. 203; 209-211). The 8th decade, starting with the oil crisis from 1973 (along with its cumulated economic effects) and also the rise of the New Right will lead to a shift towards the center of the social-democratic parties, with a reduced accent on the role of the state in the economy. This shift appears to be countered, in recent years, by a mobilization of the left against the austerity policies promoted by the right as a reaction to the financial crisis which started in 2008 .

\section{Ideological and institutional milestones in the evolution of the Romanian social-} democracy

In the Romanian space an arguably early emergence of socialist (utopic) inspired ideas, and even an attempt, with no real success, to put them into practice can be spotted in mid-1830. This happens in the form of the phalanstère/phalanstery (association/community working under cooperative principles) established at Scaieni (Prahova) by Teodor Diamant, a disciple of Charles Fourier, following his ideas, after he came back from France.

The economic and social context remains unfavorable for the development of these ideas and organizations, due to the industrial underdevelopment of the Romanian Principalities, and latter (from 1881) of the Romanian Kingdom (Proca, 2010, pp. 24-25) with the exception of some urban centers in Transylvania, Banat or Bukovina, which up until 1918 were part of the Hapsburg Empire. Within them, the (Romanian) socialist movement (in parallel with the other nations within the Empire) was much stronger than the one in the Old Kingdom. In the beginning of the $\mathrm{XX}^{\text {th }}$ century, figures like Iosif Jumanca and Ion Flueraș were some of the most well-known leaders of the Romanian socialists from the AustroHungarian Empire.

For this reason in the first Romanian socialist program $(1886-$ Ce vor socialiștii români?/What do the Romanian Socialists Want?), preceding and contributing to the subsequent structuring of the first Social Democrat Party in the Kingdom), the author, Constantin Dobrogeanu-Gherea, feels the need to justify, in a full chapter, the necessity of the appearance of socialism in the Romania. Although we can find Marxist influences in his 
program, he also writes about the topic of the development gap between the West and Romania, imposing an approach close to the revisionist one (Proca, 2010, pp. 26-27).

The Romanian Social Democratic Workers Party (PSDMR), which appeared in 1893, maintains the same moderate and "legalistic" orientation. It is established and animated by a series of intellectuals (Ioan Nadejde, Vasile Morţun, Sofia Nădejde, Traian Demetrescu, Constantin Stere, Anton Bacalbașa, along with C. Dobrogeanu-Gherea) and coexists with the trade union movement (professional workers' associations), instead of being founded on their initiative. The party accedes to the Parliament with several elected representatives and is abolished in 1899 by an episode called "the betrayal of the generous" in the epoch - the passing of a significant number of leaders to the National Liberal Party, PNL (Proca, 2010, pp. 28-29).

Beyond its direct political impact, which was limited, its importance can be put into perspective through its role in introducing into the public/parliamentary debate in Romania of some themes that were specific to socialism (universal suffrage, social/labor related rights and legislation, women's rights and emancipation) and through its indirect influence on two contemporary doctrines that came about at the end of the XIX ${ }^{\text {th }}$ century, poporanism and sămănătorism (Jurcă, 1994).

The party is rebuilt in 1910 as the Social Democratic Party (PSDR), from December 1918 the Socialist Party of Romania. Ion C. Frimu, Mihai Gh. Bujor, Christian Racovski, Dimitrie Marinescu and Constantin Vasilescu are among its leaders. The party's ideological orientation is initially moderate, following PSDMR's tradition, but it then goes through an extensive period of internal strife and organizational transformation after the Russian Revolution and the First World War/The Great Union (1918). Afterwards, in 1921 the communist faction takes the lead and the figureheads of the moderate groups are kicked out of the party, which then becomes the Romanian Communist Party (PCR). Organizationally, a social-democratic party (PSD) will be reestablished, following many phases, only in 1927 (Proca, 2010, p. 37). It will have Constantin-Titel Petrescu as its leader until its disappearance in the post-World War Two period.

Although in Romania universal male suffrage is introduced (1919), with the exception of the first organized elections, the scores obtained by the socialists/social-democrats remain insignificant. The immediate causes were tied in to the antisocialist legislation of some governments, to internal fragmentation and, in a smaller measure, to the competition represented by the radicals of PCR, a party which was legally banned immediately after its 
Issue no. $23 / 2017$

founding. The structural causes remained those of a still incipient industrialization of the country, despite some visible progress that came after 1918. But there was another socioeconomic characteristic that, if identified adequately, could have opened the way for a socialist/social-democrat message in the Romanian society. This was represented by two components: the predominance of manual labor in all three sectors of the economy and the existence of a large category (in industry, but especially in agriculture, services) without private property/ with insufficient property, ineligible for the middle class and, as a result, mostly able to be assimilated with the proletariat.

In parallel with PSD, PCR remains irrelevant when it comes to the number of members and sympathizers, being controlled, through the Comintern and the Soviet Union's Communist Party, by power structures (political and informative/espionage) from within the totalitarian soviet state, which did not officially recognize the territorial integrity of the Kingdom of Romania after 1918.

After the $23^{\text {rd }}$ of August 1944 and the shift of the PCR from illegality straight to governmental power, in the context of the soviet armies entering the Romanian territory, PSD comes to the forefront within the national unionistic government. The broader association of the two parties (PCR and PSD) will continue in 1946 through a forced alliance (rejected by a part of the PSD leadership, which tries to establish a new party) and through a forced absorption into PCR in 1948, the new party being renamed to the Romanian Workers Party (PMR). Symptomatically, the former leader of PSD, Constantin-Titel Petrescu, is politically convicted by the new communist regime, is released and ends his life in hospital as a result of the harsh treatment suffered in detention.

Post 1989, Romanian social-democracy remained divided and made up of competing parties until 2005. For the most part of this period there were three political parties whose interaction was determined, first and foremost, by the way in which each one of them related to the communism/neocommunism - anticommunism cleavage.

The most important one, the National Salvation Front (FSN), predecessor of the actual PSD, is the result of the transformation of the temporary organization of the revolutionary power from December 1989 into a party, at the beginning of 1990. Although often accused by rival formations of neocommunism, it should be mentioned that FSN was not a proper successor party, PCR being outlawed and dissolved after the $22^{\text {nd }}$ of December 1989.

Chronologically, its first opponent was the Romanian Social Democratic Party (PSDR), (re)founded at the beginning of 1990 by veterans of the interwar PSD, from where 
Issue no. $23 / 2017$

they reclaimed their continuity and legitimacy. PSDR had a manifest anticommunist orientation and joined in 1992 the Romanian Democratic Convention (CDR), a grouping of right-wing opposition parties mobilized against FSN. The situation gets further complicated starting from 1992 with the schism of FSN between Petre Roman's wing (former primeminister, perceived as being more liberal) which remains in, and takes control of the party (that at a later date becomes the Democratic Party, PD), and the majority grouped around Ion Iliescu (president-in-office), who will form a new party, the Democratic National Salvation Front, FDSN (which later changed its name into the Party of Social Democracy of Romania, PDSR).

In 1995 PD and PSDR will ally themselves in view of the elections of the following year, forming the Social-Democratic Union (USD). This alliance represents PD's access key the Socialist International, in 1996. In the same year, USD participated (as a minor partner) in the forming of the government after the elections, together with CDR and the Democratic Union of Hungarians from Romania (UDMR).

In the year 2000, PDSR and PSDR will set up an alliance, forming the SocialDemocratic Pole together with the Romanian Humanist Party (PUR). In the following year, the two parties will fuse together and PSDR (ex-FDSN, ex-FSN) becomes PSD. The absorption of PSDR will grant its access to Socialist International. The Democratic Party (PD) leaves the International, in 2005, and after its subsequent repositioning on the right (together with its affiliation with the European People's Party) ${ }^{13}$, PSD remains the sole force of the Romanian left. ${ }^{14}$

\section{The spatial approach and the institutional approach}

Even assuming that the acquiring the political power is the principal and most defining aim and trait of a political party (as authors like M. Duverger, A. Downs, G. Sartori and K. Janda do, in their definitions), it is hard to imagine today a party without an ideology. As "filters"/"gatekeepers" of the political system, and mediators between it, the state and the society/voters, the ideology fixes an identity, be it even relative and in constant change, in whose absence parties would find it very difficult to carry out any type of functions, be they

\footnotetext{
${ }^{13}$ At the end of 2014, PD (which meanwhile became the Liberal-Democratic Party, PDL) fused with PNL, under the name of the National Liberal Party.

${ }^{14}$ In the end of this section I used data from Stoica (2004)
} 
vote-seeker, policy-seeker or office-seeker. ${ }^{15}$ Ideology represents „the public face” of a party, what it wants to say about itself (Ware, 1996, p. 20). According to the same author (Ware, 1996, pp. 18-14) there are two types of approaches which can be used to explain the way in which the political parties relates to ideologies, the spatial and the institutional.

The spatial or the competitional approach stems from the assumption of the existence of a political space/continuum, in which parties and voters are self-aware and rational actors, that pursue their own interests (parties, in essence, obtaining votes to acquire power, and the electorate voting for a party that is closest to their positioning). This approach was inspired by authors such as the economist H. Hotelling (and his spatial representation of economic competition) and the creators of the rational choice theory (RCT) - especially Anthony Downs in his "Economic Theory of Democracy" (1957).

There were three types of problems identified in the case of the spatial representation approach, in spite of its obvious conceptual clarity. First and foremost, Downs was suggesting the existence of one continuum only, one space (left-right), a fact that was being questioned by other scholars who supported the rational choice theory. Therefore, authors like Ian Budge or David Robertson, back in the 70's, wondered if there only had to be one axis and not distinct ones (political, economic, social) on which the political parties' views could be represented, and also if those positions would be coherent enough with each other to give a specific identity to a party (Budge, 2006; Ware, 1996, p. 20). An additional challenge is positioning ideologies that are not usually imagined in left-right terms on a left-right axis (nationalism-antinationalism, environmentalism or green and antienvironmentalism, feminism etc.).

A second issue identified was generated by the question: "What are the elements that compose the ideological profile of a party?" Besides the doctrine, meaning documents and electoral manifestos (what a party promises it's going to do), there is an even more abstract and harder to define element - the ethos, which is, according to H.M. Drucker - "what in the past we'd call the spirit of a party, its traditions, rituals and the way it is being perceived" (Ware, 1996, pp. 20-21). Thus, according to Drucker, the ideology of a party also embraces, alongside doctrine, its ethos. Public policies (initiated, adopted, implemented by central or local political institutions, representing what a party does (and arguably more importantly

\footnotetext{
${ }^{15}$ In the Romanian politics, the recent difficulties experienced by the Save Romania Union (USR), a party newly-founded before the legislative elections of December 2016, due to the absence of a clear positioning with regards to controversial themes in public debate seem to confirm this vision.
} 
Issue no. 23/2017

than what a party says it would do), are also very important when analyzing the ideological engagement of a party. We can also mention the declarations and speeches of political leaders, either official ones or publicized by the media.

The third and last issue represents the existence of populism either at the party (with some possible emphasis on new parties) or at the political system level (with some tradition in Latin America or South-East Europe, according to Ware, 1996, p. 21). In this sort of context, the parties which access to power seems to be blocked tend to show irresponsibility in terms of policy proposals, starting what G. Sartori calls, "the politics of overbidding" among themselves (Sartori, 2012, pp. 147-149). Another possibly trouble making issue could be the existence of factionalism, in terms of different ideological affiliations within the same party (see the case of the Democratic Union of Hungarians in Romania - UDMR, according to some sources and observers - even if this could also function as a counterexample).

The institutional or historical approach underlines in essence the fact that, although parties (through their leaders or management board) can act as rational entrepreneurs in search for gains on the political market, they are not fully free agents. For every party its history as an institution matters, and its actions in the present are, at least partly, conditioned by it. Furthermore, parties which, in different countries, have mobilized a similar electorate and have supported similar ideas and programs will have a sum of common elements (Ware, 1996, pp. 21-22; Gallagher, Laver, Mair, 2002, p. 202).

The author which developed the most used typology of parties in accordance with their ideology and their political and institutional history is Klaus von Beyme. He uses the phrase "familles spirituelles"/"spiritual families" for the ideological families of parties. By using the political context of the European liberal democracies he identifies nine such families (von Beyme, 1985, in Ware, 1996, p. 22), in the chronological order of their appearance:

1) Liberal and radical parties

2) Conservative parties

3) Socialist and social-democratic parties

4) Christian-democratic parties

5) Communist parties

6) Agrarian parties

7) Regional and ethnic parties 
Issue no. $23 / 2017$

8) Right and extremist parties

9) The ecological movement

Gallagher, Laver and Mair (2002, p. 203) have a similar approach, dividing political families in families of the left (social-democrats, communists, the new left, green parties) and families of center and right (Christian-democrats, conservatives, liberals, agrarians or center parties and extreme right parties). It can be noticed that there are also nine categories; if among the families of the left we have an extra-family of the new left, from those of the center and right we lack the ethnical and regional parties.

\section{The analysis of the PSD programs. The legislative elections of December 2016 Introduction}

Concerning a distinct (and partially divergent) alignment of the Social Democratic Party (PSD) with the mainstream Western European left, several explanations and arguments have been advanced during the early '90s. Kitschelt (1992; as well as is in Lupu, 2017, p. IV) spoke of an alignment of the Eastern European left-wing successor parties (with which PSD could be associated with) to the left on the axis of controlled economy - market economy, and to the right on the axis of libertarianism - authoritarianism, in order for them to preserve the advantages of the status-qvo.

Alternatively, due to the presence of this successor type of left-wing parties in the government immediate after the fall of communism (the specific examples being Romania and Bulgaria, unlike in the other countries from the former Socialist block), the initial phases of the controversial privatization of the hyper-centralized socialist economy fell in their responsibility (Lupu, 2017, p. IV). That represented a dual contamination source, leading to the development of privatization programs by these parties (which had in their ranks leaders with "an obvious entrepreneurial profile") as well as to a slower process of privatization. To all of these, we can add up, as Daniel Seiler says (1999), that the specific reality of the area generates a cleavage among communists (neo-communists) - anti-communists (democrats) which goes past the classical cleavages of Rokkan and influences the layout of the left-right axis. What will be directly affected is the Romanian socialist/social-democratic movement, which at first is not perceived as such; in the first decade post-1989, the historical Romanian Social Democratic Party, PSDR is in opposition (and even member in adverse, right-leaning political alliances) towards the National Salvation Front (FSN), the National Democratic Salvation Front (FDSN) and the Party of Social Democracy of Romania (PDSR). 
Issue no. $23 / 2017$

Subsequently the National Salvation Front, FSN (who later became the Democratic Party, PD) has followed a similar oppositional path related to the National Democratic Salvation Front/the Party of Social Democracy of Romania (FDSN/PDSR), party from which it got separated.

Secondly, and conjunctively with the initiatives and attempts of the FDSN/PDSR to find legitimization in the field of the international affiliations (The Socialist International and the European Socialists), this type of cleavage has also generated joint efforts of the party to drop the totalitarian communist heritage ascribed to it, eventually calling for - starting with the leader of the party Ion Iliescu (currently honorary president) - a revolutionary legitimacy from the events leading to the overthrow of the totalitarian communist regime in December 1989.

Even after the adherence of the party to the Socialist International and to the European Socialists Party (in 2003 and 2005), we can still notice, in their programs, as well as in the public policies promoted by the Social Democratic Party (PSD) some particularities which cannot be found within the European social-democracy. During Ponta $3^{\text {rd }}$ and $4^{\text {th }}$ cabinets (after the break-up of the Social Liberal Union, USL: March 2014 - November 2015), although at that time the program of the PSD included progressive taxation, the Prime Minister Ponta kept using, even after the exit of The National Liberal Party (PNL) from the Social Liberal Union (USL), the minimal/flat taxation (16\%) on profits and incomes, highlighting its positive effects on the economy.

Also the messages coming from then-presidential candidate Victor Ponta during his electoral campaign for the presidential elections of November 2014 - having Victor Ponta as Prime Minister and President of the PSD as well as the adversary of the liberal (PNL) presidential candidate Klaus Iohannis - upholding his beliefs in the merits of the ethnic and confessional particularism (Romanian and Orthodox) against an opponent of German ethnicity and Evangelical denomination - proved to be peculiar, from the point of view of the laïcité (if not the anticlericalism), the universalism and multiculturalism the European Socialists were promoting for years. We can also remember one of his campaign slogans: "Proud to be Romanians".

\section{Romanian Social-Democratic Party's Political programs and manifestos}

In analyzing the political programs with whom the PSD presented itself to the electorate during the November 2016 campaign and the elections that followed in December, 
a heuristic distinction between political programs and electoral manifestoes can be made. The first state positions in terms of values and include generic measures (without a time limit in which these measures must be applied) and the latter contain concrete measures and public policies proposals.

The approach used in this analysis is a spatial-institutional one, using the left-right axis and the characteristics of the social-democratic or socialist party family as a benchmark in order to fit the proposed values and measures from PSD political documents. The qualitative-discursive method used by the author is based upon his experience as an expert in encoding the political programs of Romanian political parties between 2014 and 2016 as part of the "My Vote" project ("My Vote" is a collective academic project with researchers from the University of Zurich, the eDemocracy center, the ZDA and from the Centre for the Study of Democracy, part of the Political Science Department the Babes-Bolyai University (http://www.votulmeu. com/\#!/articles/public/About ).

\section{The political program of the PSD}

The programmatic minimalism shown by all the political parties during the $2016^{16}$ legislative elections is also present on PSD's website (www.psd.ro) where the information are presented in a general manner. The PDS legitimizes itself („Cine suntem?”/ "Who we are?” http://www.psd.ro/despre/cine-suntem) through the economic growth and an increase of the average Romanians' living standards ("party of welfare") and with its role in getting Romania to be part of NATO and the EU. Another source of legitimacy can be the PSD's allegiance to the Socialist International and membership of the European Socialist Parties. The importance of political parties for the well-being of representative democracy is also mentioned.

A true political Decalogue is present in the section „În ce credem“/ "In what we believe" (http://www.psd.ro/despre/in-ce-credem):

1. We believe in the equality of chances

2. We believe in the values of democracy, the right to private property, we believe in each Romanian and in Romania

3. We believe in state-funded education

4. We believe in state-funded healthcare

\footnotetext{
${ }^{16}$ Maybe, paradoxically, with the exception of Popular Movement Party, PMP (Lupu, 2007, p. V) - https:// pmponline.ro/program
} 
Issue no. 23/2017

5. We want a system of progressive taxation in order to reduce social cleavages

6. We want the workers to have minimum conditions by law: minimum wage, protection against abusive dismissal, paid leave etc.

7. We believe that social responsibility is not a charity, but an expression of solidarity between humans

8. We believe that the environment is something that we must leave for the future generations, thus its protection is an important objective

9. We believe that there is a need for ethical and fair trade, based on dialogue and transparency as an alternative to the liberal principle of free trade 10. We believe in multiculturalism and gender equality

These points shape a social-democratic vision of the society, according to PSD. Worth noting is the reference to the right to private property, possibly as a counter reaction to the fact that many voices have accused the PSD of communism, also the mentioning of statefunded healthcare and education, of a system of progressive taxation and (as a novelty) the idea of ethical trade. There are also some elements of the new left present: multiculturalism, gender equality and environmentalism

The section "Politica PSD"/ "PSD politics and policies" (http://www.psd.ro/\%20viziune/ politica-psd) targets the electorate of the party. This is not the "proletariat/working class" (less numerous and harder to define nowadays), but "the many" ("the common people", "those who work", those employed in commerce and state funded sectors such as education and healthcare). At the end of the paragraph there's a mention of the entrepreneurs, as well as the big and small businessmen.

The last reference is not regarding to class but communities and the importance of politics in these communities, an approach that can go with the principle of subsidiarity (ideologically originating in Christian-democracy and Conservatism) as well as with the idea of "grassroots involvement" promoted by the new left. The section ends with a message to Romanians who live and work outside Romania, calling them "the country's most important creditors" - probably the most important reference to them from any political party in Romania. ${ }^{17}$

In the other two sections, the emphasis is put on the party's need for openness:

\footnotetext{
17 A most surprising aspect, considering PSD's (and its cabinet's) attitude towards the Romanian voters from abroad, during 2014
} presidential elections. 
Issue no. $23 / 2017$

towards its own members, who are "neither barons ${ }^{18}$, nor corrupts or communists", through internal democracy and their mobilization as human resource (a typical step, we could say, for a mass party belonging to M. Duverger's typologies), towards society/supporters, enhancing the need to create/restore bridges of connection with intellectuals and towards specialists and experts (in the first, http://new.psd.ro/viziune/psd-in-2016 ) and the need to recognize and repair mistakes from the past in the second ( http://new.psd.ro/viziune/psd-isiasuma-trecutul ). Among these, it is mentioned the conviction of communism and the 1990 "University Square" episode, as well as the restoration of the relationship between the party and the Transylvanian electorate. Having in mind the need to avoid "post hoc, propter hoc" reasoning, we can ask ourselves how many of the changes occurred in the sociodemographic profile of the "typical PSD voter" or how much of the electoral score without precedent obtained by the PSD in Transylvania could have been generated by these messages.

The last section to which I am going to discuss about in this part of the article is the most ample of the mentioned ones, and comes as a completion to the 10 points (,În ce credem?"/ "In what we believe?") in order to create the imagine of what could be called a project/vision of country (http://www.psd.ro/viziune/proiectele-psd ). There are many outlined aspects and the approach is one specific to a "catch-all" of party: the need of trust, decentralization, constitutional reform, durable development, a socially active rule of law with powerful institutions. As novel themes for a social-democratic party, we can mention the outlined need to support the Romanian entrepreneurs (in a context dominated by multinational corporations), the importance of national defense (the allocation of $2 \%$ from GDP for defense being the only specific provision from what we could call the "political program" part), the need for diminishing the bureaucracy and the support for the reconstruction of the media/printed press. Finally, it emphasizes the need for a medium-long term development plan for Romania (25 years), which needs to be debated with the Romanian Academy, the society and all political forces.

\section{Electoral manifestos}

These consists of a series of seven sets of documents which contain extensive measures for the modernization of society and the improvement of life standards (justified mainly in terms of general utility rather than from an ideological perspective - again, a catch${ }^{18}$ A term used by the Romanian media and politicians, referring to the powerful (and allegedly corrupt) local political leaders, in analogy
with the power of the feudal barons. 
all party trait) accompanied by a corollary present in the beginning of almost every section: "more Romanians in the middle class"19. This main preoccupation, together with the program of financial support provided by the state for the young entrepreneurs' business start-up projects (one of the first public policy introduced by the PSD government in 2017, after winning the elections) and the maintenance of the flat taxation (16\%) for profit (in contradiction with what is stipulated in the political program part concerning proportional taxation - http://new.psd.ro/despre/in-ce-credem), along with numerous tax exemptions for various categories of citizens marks an obvious shift towards right. The only provided limitation concerning this aspect is the one on outsourcing the profit of multinational companies, to be applied starting with 2018.

Modernization proposals regard the development of road, railway and airport infrastructure, reindustrialization (with the support of the Sovereign Development and Investment Fund, FSDI, whose establishment is envisaged, and through the use of European funds, http://psd.ro/assets/pdf/Programul\%20economic\%20al\%20PSD\%20\%2022.09.2016.pdf) reducing bureaucracy, investments in health services (construction of a republican hospital and 8 regional hospitals until 2020, supporting the national pharmaceutical company, equipping county hospitals, supporting family doctors, new public health programs, prevention programs, http://www.psd.ro/assets/pdf/Programul_PSD_pentru_Sanatate_-04.11_.2016_pdf), in education/for the use of young people (development of the educational and sport infrastructure, $\quad$ http://psd.ro/assets/pdf/Programul_PSD_pentru_Tineri_si_Sport__07.11_2016_.pdf) and in agriculture (extension of irrigation systems, development of antihailing and rainfall enhancing systems, initiation of a national research \& development system, $\quad$ http://psd.ro/assets/pdf/ Programul_PSD_pentru_agricultura__28.10_2016_(1)_.pdf).

Beyond these investment and actual modernization proposed programs, one of the most important characteristics of electoral manifestos of the PSD is the encouragement for development through financial facilities and incentives, in multiple and various fields of activity, in the shape of exceptions and reductions (temporarily or permanent) of taxes and contributions. The basic tax thus remains at $16 \%$, but is reduced for small enterprises, and

\footnotetext{
19 "PSD's objective is that each and every Romanian who works hard, contributes and has contributed to the economic growth, is part of the middle class" (Liviu Dragnea, "The development and modernization of Romania", http://psd.ro/assets/pdf/Dezvoltarea_si_ modernizarea_Romaniei_-_Romania_start-up.pdf, p. 10
} 
Issue no. $23 / 2017$

there is also a proposition for non-fiscal taxes to be removed. Tax cuts have a special section dedicated to it: http://psd.ro/assets/pdf/Programul_economic_al_PSD_(partea_a_11-a)__09.10_.2016_.pdf.

We can see here a clear distinction with the solidarity principle, usually used by socialists and social-democrats through progressive taxation (thus increasing the amount of collected money) to support a high social and economic involvement of the state in order to help the disadvantaged and to support the progress of society. Another specific note is the assumed national character of some measures, such as supporting local investors in an environment dominated by multi-national corporations or supporting Romanian farmers on the European market.

Another striking dimension of these electoral manifestos is comprised of the measures that aim to raise the income/standard of living for almost all socio-professional classes. Thus it proposes an income tax cut from $16 \%$ to $10 \%$ (and an full exemption for medical doctors, IT-related jobs and anybody with an income below 2,000 RON gross/month), tax cuts for social security and medical insurance, cuts or removal of the income tax and health insurance tax for retirees (according to the level of the pension), tax cuts or exemptions for dividends, property or land transfer. ${ }^{20}$

The proposed effective growth measures proposed refer to a $40 \%$ minimum wage raise, a $56 \%$ minimum wage raise for state employees, a $60 \%$ raise in the pension point and minimum-guaranteed pension, credits of up to 40.000 lei with state subsidized interest for young people and, in effect, the doubling of the income for medics and nurses. As means to support the additional incomes the following are mentioned: the multiplication effect of income raises and investments done through the Sovereign Investment and Development Fund (FSDI), increased tax collection, absorption of European funds and taxes (limiting the externalization of profit) on multinationals. The concrete/detailed way in which the FSDI is to be capitalized, beyond the issuing bonds and providing dividends, is not specified.

In comparison to these measures targeted at a micro or medio-societal level, the more complex and ambitious plans of development - a trademark of the classical socialism and social-democracy, and which are also a part of PSD programs - seem to occupy a second place. We are talking about goals such as reducing unemployment (below 3,5\%) and creating

\footnotetext{
${ }^{20}$ Though the majority of these measures have a deadline on $1^{\text {st }}$ January 2018, they were put on hold by the debates on topics (not mentioned in the electoral manifestos) such as global household tax or the passing of the tax-paying duty from the employer to the employee, which animated the PSD governments in 2017. Not to mention the episode of the pardon and amnesty provided in the "famous" OUG (Government Emergency Ordinance) 13, issued at the beginning of the year.
} 
Issue no. $23 / 2017$

850.000 jobs before 2020, reducing the risk of poverty and social exclusion for 1.500 .000 people and increasing salaries to over 1000 euros for at least 1000000 people in the same year horizon. Furthermore, the plan to move to an economy based on innovation and the advancement of the country to the $13^{\text {th }}$ place as an economic power in Europe (from the $17^{\text {th }}$ ) are also being considered.

\section{Conclusions}

This article presents two directions of evolution considered by many to be distinct/divided - that of the noncommunist, Romanian left-wing (socialist, social-democratic - "democratic" being used here in order to signal the compatibility with the democratic political system) organized thinking and politics, along the history, on the one hand, and that of the nowadays Romanian Social Democratic Party (PSD) on the other. The first one starts developing in an atypical economic and social background, dominated by agrarian and landed economic interests and by development gaps which apparently have no connection to the industrial economy (or generated precisely by its insufficiency) and then it continues with organizational splits and realignments of exponential figures only to be dismantled too fast under the pressure of a communist totalitarian system.

The second one starts its existence in a particular way as well - neither as a successor party nor as a promoter of interwar socialism, but rather as an expression of a communist, clandestine, uncertain reformism. Left-wing party and partially "condemned" to right-wing policies (privatization), with internal struggles and involvement in dark and controversial historical episodes (Mineriadele/the Mineriads), oscillating between a normal left-wing legacy ("the noble ideals of socialism", as Ion Iliescu put it at the end of 1989) and its rejection and, at the same time, between authoritarianism and reform, PSD (former National Salvation Front/FSN, National Democratic Salvation Front/FDSN, Romanian Social Democracy Party/PDSR) creates for itself, although with difficulty and gradually (and through the alliance with PSDR) an identity contour.

The period that followed after 2000 brings certain clarifications, from the point of view of conformity (and the lack of exceptionality) of PSD programs compared to the socialEuropean democracy of which it is already an institutional part. The discussion over the ideological unification was, up until 2005, concerning the right-wing as well as the left-wing Romanian parties, but from that year, PSD remains the only left-wing Romanian party, with the Democratic Party (PD) moving to European Populists. However, to make things more 
Issue no. $23 / 2017$

complicated, the years after its 2004 electoral defeat the Social Liberal Union was set up, by allying with the National Liberal Party (PNL). At the same time, starting with 2008, the Romanian electorate became, according to the results of surveys, more receptive to the ideological dimension. Even after the dissolution of the USL, certain "deviationist" rightwing ingredients continued to exist in the political programs and policy proposals submitted/endorsed by PSD and in the speeches of its leaders.

Such a tension seems to exist at the level of political documents elaborated by the party for the 2016 November-December electoral moment, between general programs and the ensemble of proposed public policies (the electoral manifesto), the latter incorporating sets of measures traditionally seen as belonging to the right-wing economic politics. If these are proof of populism (and some would also add the term "irresponsible"), in trying to capacitate a right-wing electorate, of pragmatism or rather of a bold, creative and innovative political and economic approach remains to be proved by the future events.

A few months after winning the parliamentarian elections with an unexpected result (over $45 \%$ of votes for the Senate and the Chamber of Deputies), and despite the efforts of defining a leftist identity, the ideological monopoly of PSD ends up being challenged by a platform ${ }^{21}$ that is yet unknown and in the process of being organized, one that claims to be a part of the new European left.

\section{Bibliography}

- BALL, T./ DAGGER, R. (2000) Ideologii politice şi idealul democratic. Iași: Editura Polirom.

- BERNSTEIN, E. (1907/1899) Evolutionary Socialism. Available from: https://www.marxists.org/ reference/archive/bernstein/works/1899/evsoc/index.htm [Accessed 20.09.2017].

- BUDGE, I. (2006) Identifying Dimensions and Locating Parties: Methodological and Conceptual Problems, in KATZ R. S./ CROTTY W. M. (eds.) - Handbook of Party Politics. London and Thousand Oaks, CA: Sage, pp. 422-433.

\footnotetext{
${ }^{21}$ Demos platform (http://platforma-demos.ro/)
} 
- CARPINSCHI, A. (1998) Doctrina social-democrată, in MUNGIU-PIPPIDI, A. (ed.) Doctrine politice. Concepte universal și realități românești. Iași: Editura Polirom, pp. 175-194.

- DUVERGER, M. (1990/1951) Caucus and Branch, Cadre Parties and Mass Parties, in MAIR P. (ed.) The West European Party System. Oxford: Oxford University Press, 1990, pp. 37-45.

- GAllagheR, T./ LAVER, M./ MAIR, P. (2002) Representative Government in Modern Europe. New York: McGraw-Hill, pp. 202-232.

- HEGEL, G. W. F. (2000) Fenomenologia spiritului. București: Editura Univers Enciclopedic.

- JURCA, N. (1994) Istoria social-democrației din România. București: Editura Științifică

- KIRCHHEIMER, O. (1966) The Transformation of West European Party System, in LA PAlOMbarA, J./ WeINER, M. (eds.) Political Parties and Political Development. Princeton, NJ: Princeton University Press, pp. 177-200.

- $\quad$ KITSCHELT, H. P./ MANSFELDOVA, Z./ MARKOWSKI, R./ TOKA, G. (1999) PostCommunist Party Systems, Competition, Representation, and Inter-Party Cooperation. Cambridge University Press.

- KITSCHELT, H. P. (1995) The Formation of Party Cleavages in Post-Communist Democracies: Theoretical Propositions, Party Politics. vol. 1 no. 4 (Fall, 1995), pp. 447472.

- KITSCHELT H. P. (1992) The Formation of Party Systems in East Central Europe, Politics and Society. vol. 20 no. 1 (March, 1992), pp. 7-50.

- LENIN, V. I. (1916) Imperialismul, stadiul cel mai înalt al capitalismului, in LENIN, V. I (1970) Opere alese. București: Editura Politică, pp. 75-213. Available from: https://www.marxists.org/reference/archive/bernstein/works/1899/evsoc/index.htm, [Accessed 20.09.2017].

- LUPU, H. (2017) - PSD, în dreapta stângii europene (dosarul „Social-democrația azi”), Dilema Veche nr. 674, 19-25 January 2017, pp. IV-V. Available from: http://dilemaveche.ro/sectiune/ tema-saptamanii/articol/psd-in-dreapta-stingii-europene, [Accessed 20.09.2017].

- MARX, K., ENGELS Fr. (1956/1845) Ideologia germană. București: Editura de stat pentru literatură politică, pp.14-48. 
- MARX, K., ENGELS, Fr. (1962/1848) Manifestul Partidului Comunist. București: Editura Politică.

- NEUMANN, S. (1990/1956) The Party of Democratic Integration, in MAIR P. (ed.) The West European Party System. Oxford: Oxford University Press, 1990, pp. 46-49.

- PROCA, O. G. (2010) Social-democrația în România pre-comunistă: geneza mișcării politice socialiste și tema autenticității, in Analele Științifice ale Universității ,Al. I. Cuza” din Iași, Științe Politice. tom V/2010, pp. 1-39.

- SARTORI, G. (2012) Partide și sisteme de partide. Cluj-Napoca: Editura CA Publishing.

- SEILER, D. (1999) Partidele politice din Europa. Iași: Institutul European.

- STOICA, S. (2004) Dicționarul partidelor politice din România, 1989-2004. București: Editura Meronia.

- WARE, A. (1996) Political Parties and Party Systems. Oxford: Oxford University Press, pp. 17-49 (62).

PSD online resources [Accessed 01.09.2017-20.09.2017]:

Political programs:

- (www.psd.ro)

- http://www.psd.ro/despre/cine-suntem

- http://new.psd.ro/despre/in-ce-credem

- http://new.psd.ro/viziune/politica-psd

- $\quad$ http://new.psd.ro/viziune/psd-in-2016

- $\quad$ http://new.psd.ro/viziune/psd-isi-asuma-trecutul

- $\quad$ http://www.psd.ro/viziune/proiectele-psd

Electoral manifestos:

- http://www.psd.ro/media/stiri/programul-economic-al-partidului-social-democrat-click-pe-fotode-mai-sus-pentru-a-vizualiza-prezentarile

- $\quad$ http://psd.ro/assets/pdf/Programul\%20economic\%20al\%20PSD\%20-\%2022.09.2016.pdf

- $\quad$ http://www.psd.ro/assets/pdf/Programul_PSD_pentru_Sanatate_-_04.11_.2016_.pdf

- http://psd.ro/assets/pdf/Programul_PSD_pentru_Tineri_si_Sport_-_07.11_.2016_.pdf

- http://psd.ro/assets/pdf/Programul_PSD_pentru_agricultura_-_28.10_.2016_(1)_.pdf

- http://psd.ro/assets/pdf/Programul_economic_al_PSD_(partea_a_11-a)_-_09.10_.2016_.pdf 